\title{
Managing Mobility Driven Conflict in the Border Areas of Afar Region, Ethiopia Abdelah Alifnur
}

\author{
Samara University, Ethiopia \\ abdelahalifnur@gmail.com
}

\begin{abstract}
A community based qualitative study was conducted to assess mobility, conflict and the mechanisms of managing conflict in three selected sites in the western border areas of Afar region namely Kalkalsa, Finto and Garriro. The first two sites are found in Awra District and the latter one is located in Chifra District of Afar region. The study focused on mobility driven resource based conflict between the local community and their neighbours. Data was collected from March to April, 2017 using interviews. The study participants were 120 beneficiaries of GIZ run environmental conservation projects in the aforementioned areas. The collected data was thematically analyzed and the results showed that forced mobility is a response to climate change in which the communities of Kalkalsa and Finto move northward towards Yalo and Teru and Megale during periods of difficulty. On the other hand, communities of Garriro move Westwards to Amhara Region and Eastwards to Asaita and Afambo. Mobility is often attached to conflict since it comes in to play with basic resource. Resource based conflicts are prevalent in the study sites some of which have resulted in loss of human and animal life. The natures of conflicts vary from one site to another. Unlike in Kalkalsa and Finto, the conflict in Garriro is old existing and serious. It has also an inter-ethnic mode. Land and water are the key factors of this interethnic conflict. In an effort to handle such like consequences, communities have instituted formal and informal channels of conflict resolution. The intra-group conflicts of the Afar pastoralists are solved by indigenous mechanism of conflict resolution. Whereas the inter-ethnic and cross border conflicts are dealt by joint (formal and customary) institutions which apply different techniques. This new trend of integration between formal and informal channels is important and needs to be strengthened. The political actors in each part should work pro-actively so as to control the emerging conflict in the border between Afar and Amhara where the study sites are located.
\end{abstract}

Keywords: Mobility, Pastoralism, Conflict, Afar, Conflict Management

\section{LIST OF ACRONYMS AND ABBREVIATIONS}

DCG-Drylands Coordination Group

DF- Development Fund

DFID- Department for International Development

EPRDF- Ethiopian Peoples Revolutionary Democratic Front

ESSSWA- Ethiopian Society of Sociologists, Social workers and Anthropologists

ETB- Ethiopian Birr

FDRE- Federal Democratic Republic of Ethiopia

GIZ - German agency of International Cooperation

HH- Household

IDPs- Internally Displaced People

www.arjonline.org 
Managing Mobility Driven Conflict in the Border Areas of Afar Region, Ethiopia

IIRR- International Institute of Rural reconstruction

IJCV- International Journal of Conflict and Violence

NGO- Non-Governmental Organization

OCHA- Office for Coordination of Humanitarian Affairs

OSSREA-Organization for Social Science Research in Eastern and Southern Africa

PCDP-Pastoral Community Development Program

PFE-Pastoralist Forum Ethiopia

\section{INTRODUCTION}

Since ancient times, humans have travelled across boundaries in search of untapped resources. They also moved to conquer other societies and territories or to escape from war,natural disasters or major climatic shifts. Therefore, 'mobility' should not be restrictively associated with a pastoral way of life even though pastoralists adhere heavily to a mobile lifestyle. This chapter identifies mobility as a social process, in which resources are shared and interests are managed through conflict management and resolution processes. This article looks at pastoralist mobility in the context of conflicting interests and existing mechanisms to resolve such conflicts. It takes as a case-study the Afar people, who have a long history of mobility. The main research question of this chapter is, how can mobility be described as a social process? The following are the sub-questions of this study:

- What is the mobility pattern of the studied communities in the Western boarder of Afar?

- How mobility and resource use patterns are creating conflict between Afar herders and neighbouring Amhara ${ }^{1}$ farmers?

- How is conflict managed in the communities?

The objective of the study was to assess conflict in relation to mobility three selected sites at the Western border of Afar region. To this end, the study focused on mobility patterns and the interaction of pastoralists, agropastoralists and neighbouring peasants (herders) in those specific locations. It tries to depict the relationship between resource shortage, utilization systems and pastoral mobility. The study also aimed at describing the functioning of existing systems of conflict management in the communities to cultivate viable customary institutions of conflict management and fill the gaps observed in those institutions through formal intervention mechanisms. The targets of the study were the communities in Chifra and Awra Districts of the eastern border of Afar.

Addressing Pastoralist mobility in relation to conflict is relevant as conflicts are increasing across mobility routes due to changing contextual realities such as population and climate change.

1 The Amhara people are mostly agriculturalists living in Northern and central highlands of Ethiopia having their own regional administration. The region shares lengthy boundary with afar regional state in the eastern direction. It hosts huge number of internally displaced people (IDPs) due to the politically inspired ethnic confrontation in and around its territory. UN Office for the Coordination of Humanitarian Affairs (OCHA) cited regional reports on February 17/2019 that indicate more than 80,000 IDPs throughout the region. Besides inter-communal conflicts creating IDPs in the area bordering Northern Gondar Zone and Tigray regions, OCHA's report indicated that displaced people in Amhara also come from Oromia(Buno Bedele, Jimma, Nakemt, and kelem wellega zones), Benishangul Gumuz (kemash zone), SNNP( Bench Maji zone) and Somali regions since October 2017 (http://www.unocha.org/). This number has even risen further after the date of report. 


\section{THE Research SETTING: AfAR}

This study is conducted in Afar and mainly concerns the Afar people, an ethnic community which is spread over several countries in the Horn. The Afar people traditionally follow both seasonal and permanent mobility patterns due to the nature of their pastoral way of life. They are living in and around three international borders, spreading across the borders of Ethiopia, Eritrea and Djibouti. The Afar people constitute a good proportion of populations in these three states. The Ethiopian Afars who constitute focus of my research, possess a wider geographic area stretching as far as Eritrea in the north, Djibouti in the North East and Somalia in the East.

Unfortunately, the Afar people were denied their rights to unrestricted mobility during the subsequent regimes. The imperial regime has instituted Awash Basin Authority where its initiatives at that time greatly restricted the mobility and resource access of indigenous Afar community. The Dergu regime also has forced the centuries-old system of rule (sultanate) to decline and ordered the communities to institute pastoralist associations and be sedentary. They were ordered to graze in protected tribal areas that were allotted by the regime. Similarly, EPRDF (incumbent since 1991) pursued a large-scale land dispossession of locals occurred with the huge Tandahoo Sugar Plantation Scheme that restricts pastoralist mobility. Tandahoo Sugar Factory is the largest in East Africa established in Zone One along the Awash River Basin. It has created range land and water insufficiency problems which cannot be counterbalanced by its return to the local community. ${ }^{2}$

Dynamism in natural conditions has brought a shift in the patterns of mobility of the pastoralists in a way that triggers conflict.Conflict exists in all periods of human history. Archaeological findings, anthropological interpretations and historical records indicate that people have been engaged in armed conflicts since the prehistoric period (Mohammed, 2001). However, the history of pastoral societies is particularly tied to social conflict with both positive and negative outcomes. Though the scope and frequency varies, conflicts are common in pastoral and agro-pastoral areas (PCDP, 2013).

When it comes to Ethiopia, it is not different as pastoral conflicts have struck Ethiopia in different forms for centuries, and are thus not a new phenomenon. However, during the past two decades the country has experienced an increase in the frequency and intensity of violent inter-ethnic conflicts (Løber\&Worm, 2015).

Ethiopia's eastern peripheral lowland is home to the majority of the country's pastoral and agro-pastoral communities, and the scene of rampant local conflicts. Conflict occurs in different corners of the region. For instance, in the border areas between Afar and Amhara;Afar and Argoba; Afar and Tigray; Afar and Karrayu Oromo's as well as Afar and Issa Somalis. All such communities have their own way of handling conflict.

\section{Assessing Mobility And Conflict}

Mobility is sometimes considered as an adaptive strategy as it allows pastoralists to adjust to changing weather conditions without permanently departing a certain fixed territory. It is fundamental to pastoralists' strategies of coping with unpredictable rainfall, livestock diseases, and use of scarce natural resources (Van den Akker et al., 2015). Mobility further allows simultaneously exploit more than one fixed environment during climate change. The existence of well patterned mobility enables the afar to make their living without over utilizing and destroying the environmental resources and existence of pastoralism, agro-pastoralism and farming side by side for centuries (Getachew, 2004).

2 Normally, pastoralism is a way of life tuned into the natural conditions of geographic area known for aridity. Pastoral communities in Ethiopia live in the most water and pasture deprived areas naturally. Pastoral lands in Ethiopia experience low annual precipitation, averaging between 400 to $700 \mathrm{~mm}$. In many areas, droughts occur on a regular basis. As a result, pastoral land use depends on scarce water supply from the rivers (Stanford \& Habtu, 2000). 
Pastoral livelihood is an outgrowth of resource scarcity such as rain. The unpredictability and uneven distribution of rain across areas pushes pastoralists in the two study zones (Zone 1 and 4) towards other alternative zones. The short supply of Water particularly in Garriro forced them to undertake hour's long journey towards Mill River. Short availability of pasture in Finto compel the pastoralists to take their livestock in to an area located hundreds of kms away from their residence.

Mobility allows pastoralists to cope with the problems of water and pasture. According to Yaynshet and Tafere (2004), Mobility enabled the North Afar pastoralists to use the spatially variable rangelands for a limited period of time. Likewise, Getachew (2004) clarified that a migration of the Afar makes their land use, settlement and herd management system highly efficient and well organized systems which enable the afar to make their living without over-utilizing and destroying the environmental resources.

It is further known that livestocks are affected from long journey. But northern Afar pastoralists are using mobility as a escaping mechanism from herd endangering diseases and conditions. A group of herders can leave a particular rangeland micro-patch not only due to depleting feed and water for their animals but also due to other enforcing factors such as the presence of biting flies, mosquito, ticks, and predators (Yaynshet, 2004). Mobility is also a significant tool for exchanging information and forming extended relations with different groups. In case of the Afar, exchanging information (xaggu) is often tied to mobility as local people often make deliberate mobility to seek or deliver information about the distant situation. Mobility can therefore be understood as a response to optimize livelihoods of pastoralist communities, as :

- coping strategy of drought;

- mechanism of efficient resource utilization;

- $\quad$ strategy to optimize herd safety; and

- $\quad$ an exchange mechanism for information.

Mobility has also negative consequences. Seasonal mobility and constant search for adequate pasture and water makes health care, education, water, electricity, and financial assistance difficult to provide. Alemayehu (2016) noted that mobility and conflict are major detractors of delivery of education in pastoralists' district. The long journey may also claim the life of human and livestock population. Besides, it creates conflict.

In clarifying the impact of mobility on conflict, Gakuria (2013) stated that disputes flare up between farmers and pastoralists and among pastoralist themselves as migrating camel and livestock herders, in search of water and pasture for their animals during the dry season, would sometimes graze on farmers' lands or other livestock herders grazing lands and use their water points. Here we can say that mobility triggers conflict, if not causes it. Lewis Coser (1995) interpreted conflict as the struggle over values, claims to status, power and scarce resources in which the aims of the opposing parties are not only to gain the desired values but also to neutralize, injure or eliminate rivals.

More recently, Miller and King (2005) defined conflict as a confrontation when a party aspires towards incompatible or competitive means or ends (which) may be either manifest, recognizable through actions or behaviour, or latent, in which case it remains dormant for some time as incompatibilities are unarticulated or are built into systems or such institutional arrangements as governments, corporations, or even civil Society. Conflicts can be divided into Intra-group and Inter-group Conflicts. Conflicts could arise within a family, clan or other ethnic groups (PCDP, 2013).They may also arise between two different pastoralist groups or between farmers and herders. For instance, Farmer-herder conflict is an enduring feature of social life in the SudanoSahelian Zone. So, understanding farmer-herder relations is key to conflict resolution or management (Turner et al., 2004).

Conflict can occur due to various reasons. But the view that pastoral communities are traditionally warlike and 
aggressive do not hold true. It is rather a myth as conflict happens not only in those communities. Globally, it is predictable that conflicts will arise where resources are scarce and not shared fairly; where there is little or no communication between the groups in conflict; where the groups have incorrect ideas and beliefs about each other; where unresolved grievances exist from the past; and where power is unevenly distributed (Swanstrom \& Weismann, 2005).

According to Bekele (2010), resource-centered orthodoxies have recently been challenged. Instead, it is widely argued that contemporary conflicts among East African pastoralists are driven not only by scarcity of pastoral resources (which was prominent in the past)but also by competition over new sources of revenue (e.g. government budget)and control of market centers and strategic places. Thus, he asserted that resourcecentered solutions are therefore unlikely to bring sustained peace in these areas.

In pastoralist community of Ethiopia, major causes of conflict among others include competition for pasture and water (PCDP, 2013). Conflicts of both Intra and inter-clan type occur in low lands in time of scarcities on water and grazing resources. As the population number is growing and disasters are become more frequent and intense, resources have become scarce and traditional coping mechanisms have been pushed to the breaking point and occasionally giving rise to conflict (Van den Akker et al., 2015). For instance, in 2000, three major conflicts occurred between the major pastoral groups in Borena lowlands: Borana versus Garri, Merehan versus Digodi, and Digodi versus Borana). These conflicts in combination with severe drought resulted in the death of hundreds of people and dislocations (Dejene \& Abdurahman, 2001).

In Afar and its surroundings, differences of value systems do exist between Afar pastoralists and others. But such differences were not primary sources of conflict in the previous times. Rather, past conflicts occurred for two basic reasons: encroachment of a living space (without agreement) and making use of scarce resources (without consent). For instance, a wide-scale westward expansion of Issa-Somalis in the past decades that led to recurrent bloodshed between the two ethnic groups, most notably in 2002 (Bekele 2010).

In addition, invasion of afar boundary by Tigrigna speaking ethnic groups from the North West direction is another example of territorial conflict. DCG (2004) elaborated that in the period prior to the Italian occupation, the Afar experienced a series of raids from the Tigrayan highlanders generally and the Wajirat and Raya communities in particular. In what they locally called the Gas (Gad) expedition, Tigrayans mobilized hundreds of villagers for the raid, which culminated in a considerable loss of lives and property from both sides. DCG (2004) also added that socio-cultural factors such as the quest for social honor and prestige were important causes though economic ones were more propelling in the above case.

\section{Strategies of Conflict Management}

Conflict management is an approach taken when resolution seems to be impossible. As Miller and King (2005) stated, it refers to the measures that limit, mitigate and or contain a conflict without necessarily solving it. It requires different levels of intervention. According to Akpuru-Aja (2007), conflict management assumes an intervention mechanism, including monitoring and evaluation of conflict behaviours and the degree of compliance to resolutions on ending violence, demobilization of arms, or effecting concessions and remedies, which are very vital in easing tensions by all the concerned parties to the conflicts.

A report on Pastoralist Community Development Program (2013) revealed that pastoralist and agro-pastoralist communities use various mechanisms to resolve conflicts. First, they use traditional/customary mechanisms in which community leaders, clan leaders and prominent community members have a duty to administer, manage, and mediate conflicts between different groups of community and individuals. The second is through modern institutions where individuals and community groups lodge their cases to local courts and the kebele administration. In recent years, this system has gained prominence, particularly among the settled crop farmers and agro-pastoral population. For instance, in the Argoba special District, the government has established peace 
and security committees comprised of elders, clan, religious leaders, and the District administrator, etc. This committee handles cases, which goes beyond the management by the local elders.

\section{The Social Organisation of The Community}

Studying mobility or conflict requires an investigation of the existing social organization, way of life as well as system of interaction in those communities. The study communities are collectivist in their way of living identified by polygamous marriage and extended family structure. Central to the Afar social organization are decent and affinal ties. The Afar have a patrilineal decent system based on which a person belongs to a particular clan (mela). Afar settlements are composed of a mixture of clans although each locality is identified with a major clan and affines. This makes it easier to organize social, economic and political support in times of crisis (DCG, 2004).

The social organization of the study communities is hierarchical consisting of the supreme clan, clans (Mela), lineage groups (Afa) extended family (Dahle) and household unit (Buraa). ${ }^{3}$

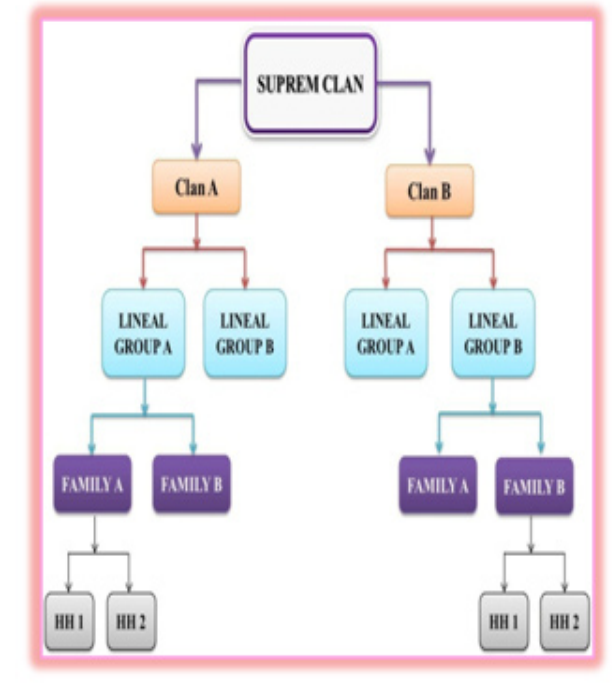

Fig1. Social organization of the Community Under study

In Hidelu (Kalkalsa), a clan called, Alla'ayto-goharto is dominant and is extended /dispersed far to Gulina and Teru Districts. Other clans include Hunda-humedo, Kadda-humedo, Ali-gayya, Lau-ala'aytoo and Asabboora. On the other hand, the social organization in Garriro is formed from the supreme clan called Arabta and eight clans with their own categories. The clans include Haddoda, Bedihitto, Adanto, Utbantto, Namelalite, Bosali, Nessar and Bulokto. In addition, the control kebele, Finto, has such clans as Hadarmu, Hayssantu, Muhto,la'ado, Gaminto, Koborto, and wolwalo.

The clan-based structures consist of individual clan leaders (kidu-abba), collective decision makers (makabantoo) and enforcer (Fie'ma aba). The latter is an adult or youth concerned with managing internal (domestic) affairs of a neighbourhood or a kebele.

\section{RESOURCE OWNERSHIP AND USE}

The key resources in the study area constitute livestock, land, water, and pasture. The resource base in the study areas is declining from time to time due to drought. Key bases are seriously affected despite efforts by GIZ to rehabilitate the areas. Due to this, there is collision of people over resources.

3 Family refers to the extended family composed of one or more households, HH: refers to Individual House Holds which together form A Family. 
As far as water is concerned, the pastoralists in Kalkalsa, Finto and Garriro mainly rely on rivers for watering their animals. The people of Hiddelu and Finto mostly use Awra River for watering their camels. On the other hand, the people of Garriro who live at the fringe of Chifra town use Mille River. Abdulatif and Ebro (2015) have explained that the major sources of water for livestock in Chifra District (where Garriro is a part) are permanent rivers, temporary rivers, ponds and traditional wells. They also report that the source of water for animals and human beings are the same. This implies that the water is not clean and there is critical water shortage during the dry season.

In addition to such rivers, there are also alternative man-made water reserves used by the study communities which are mostly seasonal. These include, hand dug wells, shallow ponds and deep wells. In the communities, access to such reserves is open to all clan members.

Coming to land resources, the regional land law dictates that all forms of non-grazing land is under the direct control of the state while grazing land is allowed for usage by various clans. Accordingly, each clan owns a patch of territory, which is exclusively owned by its members. The clan land and its borders are clearly known to members and to members of neighbouring clans. The tenure over clan land is communal and each clan member has use rights to land and resource of its clan land (Getachew, 2004).

Unlike in Hiddelu and Finto where the people are purely pastoralists, the people in Garriro are agro-pastoralists. As a result, arable land is a critical resource among Garriro residents. Arable land and irrigable land are distributed to locals to produce grains side way to cattle keeping. But range land is commonly owned.

The range land in the study area had exhausted basic pasture reserves for several months of the year. The reserves (for instance in Finto) do not stay for more than three months to feed animals. In this respect, kalkalsa (Hiddelu) is relatively better condition but still its range is deteriorating. Due to this, pastoralists move in to Yallo, Teru, Kelo, and Gewane. Better than Finto, pasture reserves in Garriro also persist longer. As an alternative to migration, the agro-pastoralists in Garriro supplement animal feeding by crop residues and purchased fodder.

\section{SOCIAL INTERACTION}

The system of interaction in the study community: it is more of kinship based. But, beyond kinship ties, the various clans and lineage groups in the three selected kebeles are engaging in a complex and dynamic process of cooperation, conflict and consensus as well as confrontation. The institutions of community cooperation are Zakat (alms) and other informal ties. According to PDF, IIRR and DF (2010) the Irbu are members who ask for receiving support (Zakat) as they are people who lost animals due to epidemics or raids . On the other hand, clan based arrangements are manipulated in acts of defending community boundaries and resources.

Giving the mobile nature of the study communities and common ${ }^{4}$ historical background, contacts are created with other pastoralists or non-pastoralist communities.. Such groups therefore, have an interaction with ethnic and tribal groups beyond the circles of those kebeles. For instance, pastoral communities in Garriro have interaction with neighbouring Amhara ethnic groups. They exchange livestock for certain food stuffs including khat in the markets.

Most of the time, the interaction among members of the same clan is build up on the principles of trust, mutual cooperation and solidarity. Pankhurst and Piguest (2004) briefed that historical relations between highlands

4 A large proportion of the present day wollo area and Afar region had common political history. Until 1991, both of them were administered under the same administrative boundary. They become separate boundaries in 1991 when Ethiopia adopted ethnic based federalism. The federal system has benefited Ethnic Afars in securing their identity though the region appeared to be the least served in terms of basic services and infrastructure. At the present time, Ethnic Amharas are dominant dwellers of major towns in Afar region. This indicates the continuity of relation between people of the two areas . 
and lowlands have been characterized by periods of conflict and coexistence.... Interrelations between highland agriculturalists and low land pastoralists have involved some complementarity, notably in exchange of livestock for grain particularly in times of hardship.

Solidarity is expressed through collective resource and information sharing. It may take also the form of sharing punishments when one of a clan member is punished for the negative acts he commits up on other nonmembers. According to Bekele (2010), any incoming compensation will also be shared among clan members. Indeed, the principle of collective (as opposed to individual) guilt and responsibility for infractions against outsiders forms the basis for solidarity within Afar clans. However, there are occasional feud and bloodshed even among members of the same clan due to hatred and the intention to revenge. Beyond this, inter-ethnic confrontation and conflict is also observed at western border of the region.

\section{RESEARCH METHOD}

\section{Description of the study Area}

In terms of the geographic area the following needs to be noted: Afar region is strategically located and served as Ethiopia's entrance to the Red Sea port (having great economic and political importance). It has five zones and 32 districts. The research was conducted in Garriro kebele of Chifra district and both Hidelu and Finto kebele in Awra district of Afar regional state, Ethiopia. From Hidelu kebele, Kalkalsa village was particularly considered. ${ }^{5}$

Chifra District is part of Zone 1 Administration of Afar regional state and located near the base of the eastern escarpment of the Ethiopian highlands which. It is bordered by Dubti District in the east, Amhara region in the west, Administrative Zone 4 in the north and Mille District in the south. The District has two rainy seasons, 'Karma' (long rain season) which appears from mid-July to mid-October whereas 'Sugum'(short rain season) occurs from March to end of April.

Awra district is Part of the Administrative Zone 4 in the Afar Region of Ethiopia. It is bordered on the southwest by Ewa, on the West by Gulina, on the north by Teru, and on the east by Administrative Zone 1; the Logiya River defines part of its South Eastern boundary.

\section{Research Participants and Method of Data Collection}

The study applied qualitative approach. Accordingly, data was collected through interviews from March toApril, 2017. The interviews were undertaken by support of translators who are fluent in Afar language. The collected data was thematically analysed and the results are presented in the subsequent parts.

Since this research work was funded by GIZ in collaboration with ODI (Overseas Development Initiative), the selection of sites was done in line with the GIZ intervention Districts with conflict threats.. But, one kebele (Finto) was added as a control site with the intention to see comparative differences in mobility, resource use and associated conflict situations.

The study participants were 120 beneficiaries of GIZ run environmental conservation projects in the aforementioned areas. They were selected based on their involvement in the environmental conservation activities of GIZ. The participants in Garriro and Kalkalsa were contacted through mentors on each site while those in Finto were contacted via the kebele administrator.

\section{RESULTS AND DISCUSSION}

The results reported from the study concern the changes in mobility patters of the community; the procedures followed; the conflict over resources that result from the activity on the trajectories; and the conflict management in the area.

5 Kebele is the lowest unit of formal administration. A group of kebeles form woreda/district. 
Managing Mobility Driven Conflict in the Border Areas of Afar Region, Ethiopia

\section{Mobility Pattern of the Study Community and Procedures}

Informants from Kalkalsa and Finto reported that they move northward in to Yalo, Teru and Megale during periods of difficulty. In rare cases, they march as far south as Gewane. On the other hand, the communities of Garriro move westwards to Amhara Region and eastwards to, Asaita, Afambo and Detbahir.

The people are moving in groups belonging to the same clan or neighbourhood. The pastoralist movement in Finto and Kalkalsa do not involve the entire family members except in a rare case. Usually adult men representing each household are main actors taking livestocks together with them and stay for months. On the other hand, elderly, females and children are made to remain at home keeping house and managing domestic property.

The time to kick off of mobility for kalkalsa and Finto pastoralists is December. The main drive behind this mobility is seeking pasture for animals. They stay on the area of destination nearly for half a year ranging up to May. But some of them return to their area of departure early April when there is a short shower of rain (locally called suggum). The period from May to early June is most difficult season identified not only by demand for pasture but also by strong demand of water as it is a time when wells are dried. Thus, it often requires a journey covering long distance. A delay of this rain leaves the pasture deteriorated and animal fodder endangered. This pushes the communities to relocate in to the aforementioned destinations.

Unlike the pastoralists in kalkalsa and Finto, Agro-pastoralists in Garriro used supplementary feeds for their animals. But they are not relieved of mobility. Especially, months immediately before the rainy season (karma) are times of forced mobility. So, it can be said that a delay in Karma rain is a push factor in Garriro. The same is true for other areas. For example, a lack of rain in 2016 due to El-Nino had a drastic effect on study communities resulting in massive exodus and change of conventional migration routes. For instance, the pastoralists in Finto do not regularly use the Gewane route except in such extreme circumstances. The shores of Awash River hold pasture reserves. But the Security problems in Awash valley (a hub of Antagonist Isa groups) by and large, limits mobility towards that. That is why the people of Garriro avoid taking a route down towards to Zone 3 .

For more clarification of the directions, look at the following map.

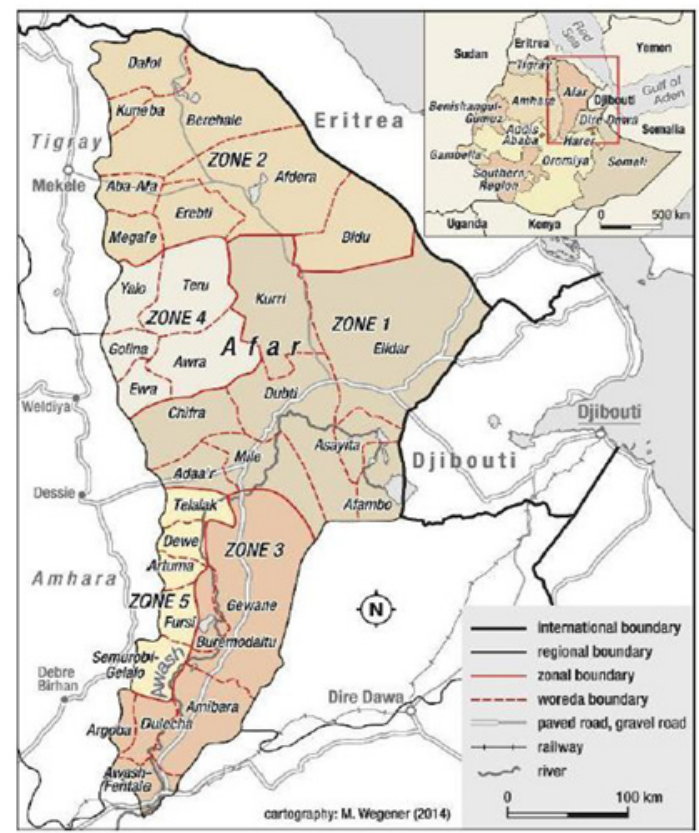

Fig2. map of Afar Region, Source: (AHT Group, ICON Institute, Veterinaires sans Frontieres Germany, 2016)

People are mobile in cases where there are temporal and spatial variability in the distribution of resources. 
When resources of a certain area are drained, communities drift in to other areas and return when the original place is recovered in terms of pasture. Unlike forced dislocation, pastoralist mobility is initially arranged following certain procedures.

The study participants in all sites stated that there is no random pastoral mobility as an outsider may think. Mobility in the context of Finto and kalkalsa pastoralists and Garriroagro-pastoralists is a planned operation. They exploit Kinship networks and religio-political correspondences as tool to arrange the routes of mobility. For instance, assistance and consultation of prominent Shiekhs (Islamic Religious Scholars, acting as community representatives) in neighbouring Habru District are often sought by the Garriro agro-pastoralists before moving in to the area.

Since the afar people have a tradition of arranging conditions before moving from one area to another, conflict happens only when such arrangements fail to materialize as they are planned

\section{Conflict and Resources}

Inter-group conflicts arise between Afar lowlanders and pockets of neighbouring Amhara communities in the highlands due to the following factors:

\section{Cattle Raiding and Conflict}

According to informants, conflicts arose between Hidelu and Finto Kebeles at the end of 2015 because of camel theft/raid. In that moment, pastoralists from Hiddelu took one camel from their counterparts in Finto. In response, members of Finto took two camels belonging to Hiddelu Kebele pastoralists. This has caused strong conflict case to the extent that becomes out of the control of clan leaders.

\section{Water Based Conflict}

There was a conflict between Kebeles of Chifra District and Sodoma area of Habru District. Chifra belongs to the afar whereas Habru District belongs to the Amhara. The cause of this conflict was water sources in Sodomma called Zemzem and Akela over which the afar agro-pastoralists are denied access by the host community. The Afar pastoralists claim that the water source of Akela is meant for them and the Amharas as the area is located nearby to the border line. But the Sodomma herders do not accept this claim and they want to secure exclusive control of this water.

Another case of conflict in the vicinity of Garriro is the one that was emerged between the Afars and Gafera herdsmen. Gafera is a place in Habru District of North Wollo Zone where there is a water source developed by government. This water source has different names by each group. The Afars call it "Afar Ela" which indicates their affiliation to this water source. But the Gafera assume unitary possession right over it. This ownership disagreement created conflict now and before.

The time and direction of mobility as well as the duration of stay is determined by availability of water and pasture. In periods of karma (rainy season) people in all sites remain in their place of residence because animal fodder and drinks are accessible. Conversely, they move to other areas during dry seasons and stay for a long time until the times of abundance. In the literature(such as PFP,IIRR\& DF,2010), it is written that the movements of Afar, Somali and South Omo pastoralists are dictated by the seasonal flooding of the Awash, Wabi-Shabelle, Ganalle and Omo rivers, which threaten lives and livelihoods. But, the situation of the study communities in 3 sites does not reflect this reality since Awash River is not close to these communities.

In some of the above cases, conflicts are not completely solved. But regular attempts of concession or cooling down tensions is made by representatives of the conflicting parties, particularly elders. 


\section{Land Based Conflict}

Land as an environmental cause of conflict can be seen in a literal sense when access or allocation of land purely as an environmental resource (e.g. for farming) creates conflict due to perceived scarcity. Scarcity of land is occasioned by land degradation in tandem with other demographic, economic and political factors such as population pressure and inequitable distribution of land.

In Awra District (where Kalkalsa and Finto are found), villagized kebeles are known by internal conflict because of the disagreement over boundary of arable land and sometimes the conflict spills over to neighbouring Kebeles other than sites of villagization because of the kinship links.

Unlike the water-based conflict, land based conflict in the borders of afar and Amhara at Chifra is long existing one. A place called 'Shul-gora' is a disputed territory among the two.

Recent conflict occurred at the month ofJuly2016 and continues up to November 2016 when time comes to harvest crop. According to informants from Afar, the conflict took the lives of six Afars and wounded 14. It also claims the lives of Sodoma Amharas and wounded unknown number of them.

The common trend in the conflict is to control the so-called 'Mishig' (fortification). It was a natural terrain used at this disputed territory by the Sodoma Amharas to defend themselves from the incoming Afar agro-pastoralists. Previously, the Afars were able to control this fortification when the Sodomas were not in alert. This created difficulty to harvest a crop belonging to Sodoma peasants in the nearby area. As a result, the Sodomas mobilized the whole member and deploy portion of the community force to stand in guard while others collect the crop at the time of harvest. Meanwhile, the Afar agro-pastoralists left the area.

At a time when the Afars leave, Sodomas(ethnic Amhara muslims) never move beyond the fortification deeper in to Afar main land because their sheikhs have firmly warned them. Despite these confrontations and victims, the communities have best habit of temporary consensus building and agreement through their tribal representatives.

\section{Pasture/Range Land based Conflict}

Pasture is also the main cause of conflict in the area especially when there is drought. Most of the time, pastoralist movement associated conflicts occur when there is Desso(enclosure) or long existed hatred with people in the place of destination. The pastoralists in Finto face conflict during their movement in to other area. In explaining this, one of the informants from Finto kebele said:

"During drought season, we move with our cattle to a far distant area. In our way (to Gewane), we come across the Issa pastoralists with whom we inter in to confrontation and conflict as they attempt to attack us."

According to informants, agro- pastoralists of Garriro also move to neighbouring Amhara territory with or without an open consent of the host community in cases of drought. Whenever there is an open consent, the parties agree to trade animal fodders (hay and other sorts of conserved grasses) among themselves. In such occasions, reciprocal arrangements are created. Indeed, that is true as there is a sense of trust and confidence among the Afar pastoralists in Chifra and Amhara herders from Worebabu District. This situation has initiated the Afar agro-pastoralists to cross the boundaries of neighbouring people even without an open consent by the host. An interviewee described the condition saying

"We have no conflict with the people of Worebabu. We go to them with our animals and they come to us with their cattle in times of shortage of rain. Even the Gafera use to do the same with us."

Unfortunately, things go on a wrong way as the Gaferas prohibit the incoming Afars from sharing pasture. In talking about the problem following such occurrences, one of the informants said that 
Managing Mobility Driven Conflict in the Border Areas of Afar Region, Ethiopia

"Things worsened when the neighbouring Hadere Amharas (of Worebabu) reportedly sided with the Gafera against the Afars. The condition created a counter mobilization of all Afar kebeles in Chifra against the joint Gafera, Hadere and Sodoma Amharas."

Now the problem becomes tense, and goes on until killing happens. The Gaferas attacked an incoming afar people within their territory. In response, the mobilized Afars from Chifra marched towards Gafera and raid more than 100 cattle. They slaughter some of the animals and kept others in their hands.

Last but not least, there are kebeles from Awra District that are bordered by North Wollo area of Amhara region and known for sporadic conflict. These include Deraytu, Hidda and Ali-marih-masgid. Transgression of boundary during drought is the cause of conflict in these areas. It is expected to have a wide potential for spilling over conflict in to other kebeles unless it is successfully resolved.

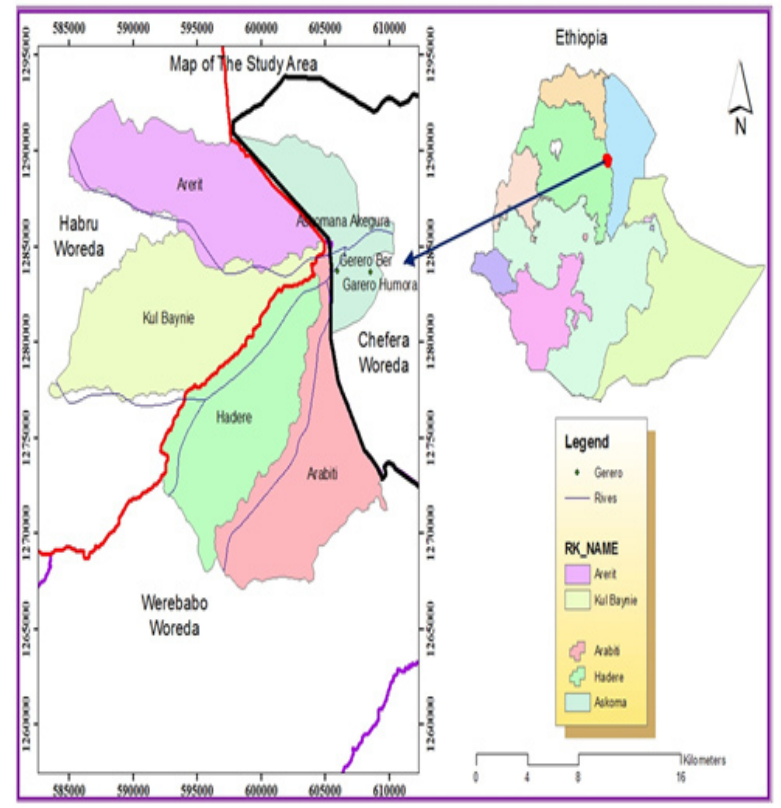

Fig3. Map of the study area4.

In general, the trend of conflict is increasing in the past five years due to the recurrent drought facing the afar people. The pattern of using land, water, and other natural resources among the neighbouring agro-pastoral communities follow a different form than the Afar. Thus, conflicts emerge when two groups collide at the same resource which belongs to one of them and is in scarce supply. Besides resource, elitist mobilizations from both sides were also developing until the 2018 nationwide political transition that allows the return of Afar elites led by Sultan Hanfere Ali Mirah ${ }^{5}$ from abroad and negotiate with Amhara regional administration.

\section{Conflict Management in the Study Area}

Conflict management requires setting up new institutions of conflict management or using available ones, identifying actors in those institutions and arranging jurisdictional matters among them. It also requires social processes aimed at bringing antagonists together.

6 In the above map, it is important to note that the Hadereare belonging to Worebabu District of South Wollo. Whereas the Gafera and Sodomma belong to Habru District of North Wollo zone. The latter two areas specifically lay in Arerit and Kulbayne sites.

7 Hanfere Ali Mirah is the son of the late prominent sultan, Ali Mirah. He is a renowned personality in the region exercising customary leadership of the people as a heir. Indeed, he is also able to influence political decision making because of the respect that he enjoys from the Afar people. 
In agreement to the above requirement, article 78 (5) of the Ethiopian constitution allows regional state councils have the power to establish or give official recognition to religious and customary courts to adjudicate disputes. Thus, the Afar religious courts are instituted with branches in different parts of the region. In addition, the Afar community have their own customary institutions. They are functional throughout every district in the region.

More specifically, the three institutions of conflict management in the study sites (kalkalsa, Finto and Garriro) include 1) Legal Courts and/or formal administrative agencies, 2) Customary institutions and 3) Sharia courts.

The actors involved and the techniques used in each case are also different even though they may sometimes overlap. In case of legal courts and/administrative agents, the actors are professional jurists who make up tribunals or due process of law to see conflict cases and provide judgements. Such agents like kebele administrators, district or regional leaders, social workers, police force, peace committee, military are responsible to apply the court rulings. In case of customary institutions, the actors are clan leaders (kidu aba), tribal councils (makabons) and executive agents (fiema aba) and elders. Under sharia courts, actors are called Qadi, religious jurists.

In all study sites, the administrative political elites have excessive power to act but the normative tradition at the societal level restricts them from applying their decisive power except in some apparently politicized conflicts. In addition, actors in customary institutions have wide mandate. For instance in all study sites, the kidu aba, the makabons, and elder have mandate to use customary laws (afar ada), to negotiate, to decide and punish offenders, to recommend the timing of formal intervention. Due to this, the formal administrative agents prefer to play a supportive and facilitator role to customary establishments or sharia courts rather than playing a leading one.

Each of the three mentioned actors cooperate and jointly conduct social processes in order to alleviate a single conflict case without relinquishing the authority vested on them. For instance, the land based conflict in Garriro was complicated in 2016 requiring the religious blessings, cultural feasts, negotiation and formal court decisions. After several weeks of bloodshed, Initial efforts were made by the peace committee of conflicting areas to communicate the recent developments regarding the conflict. This committee is assigned and assisted by the kebele administration agents.

Based on earlier communication, the committees initiated a peacemaking dialogue where the community representatives (elders)of both sides meet face to face. Accordingly, elders of the Afar went to the sodomma area and deal with the sheiks and elders of sodoma Amhara in order to avoid conflict.

In the long process of dialogue, the joint parties review the details of what was happening in each others' side during the conflict including the acts of instigators, the violations of previous pacts, the damage happened to both sides. After dealing all these, the two sides arrive at a consensus to pay compensation for one of the groups-to the sodoma Amhara who lost hundreds of cattle from raids. Conversely, the sodomma agree to avoid any retaliative act in the future. In the meantime, the political administrative body of Garriro kebele decided to pay the compensation on behalf of the clan (involved in perpetration) by selling the wheat flour that was supposed to be distributed to them in the form of aid. In this way the fractured relations were mended for at least the time being.

To bring the agreement down to the bottom, the two negotiating teams hold a joint community level briefing and issued orders for their respective community members to respect the pact. This was done at a feast prepared by the joint communities. In case of the Afar, the Fi'emaaba checks and assures whether the agreed pact is maintained in its domain. It is responsible to control young members from violating the pact by making regular patrolling of the area. It is vested with the power to punish individuals who deviate the community norms and agreements. In this sense, it is a regulative body like a local police force while at the same time calming and redirecting members towards peace. 
Despite these efforts, there is a continued occasional animal raid between the conflicting bodies as the truce is violated in the period following it. The main road linking Woldiya and Chifra towns via Sodomma route was closed. More than ten people including a police officer were killed. Under this condition, the matter becomes serious and above the control of clan leaders and the elderly. The military camped in the nearby area largely has a symbolic presence. Military intervention was delayed until the closing of 2017-after my field data was collected- due to lack of commitment by the political administration. As a restraining move, the military banned the disputed area for both of the conflicting groups. However, the military had a temporary mission; soon it left the area although the prospects of conflict remain to exist.

The above story tells us how the customary institutions are integrating with the formal administrative system. To further elucidate the view of the community on matter, Participants were asked to specify the suitable condition for government intervention. Majority of those in Garriro reported that they prefer government to intervene even though clan leaders do not necessarily invite it as far the conflict is escalated. They urged government machinery (authorities) to act under the current time to successfully control the conflict. They also admired experience of the military intervention in the past when the same conflict was escalated. But in Hiddelu (Kalkalsa) and Finto, informants said that the government should intervene only when there is invitation by clan leaders.

A similar trend of cooperative joint involvement by the customary and formal agents is made to solve conflicts between Finto and Hidelu. As it is mentioned in the previous section, the cause of such conflicts was camel raiding acts by the groups. In order to handle the case, the District administration was involved after earlier arrangements were made through clan leaders and do not succeed. Its way of involvement however was not a legal proceeding. Instead, it was a mediation by which an agreement was reached to give Finto five goats, one camel and $20 \mathrm{ETB}$ as compensation.

In addition to the aforementioned techniques of negotiations and mediation, arbitration is also used sometimes. For instance, it is applied in Malbo assemblies (council of clan leaders). A good example of this is one that happened between two Afar clans in Chifra, one from Garrio, the other - named Doda from nearby ta'eboy area.

When people of different clan enter in to conflict, the Makabons (neutral decision makers drawn from a clan or more clans not taking part in the conflict) will be called and meet the leaders of conflicting clans. In the meeting, cultural and religious rituals are performed by slaughtering animals. Interrogation of perpetrators is made and their confessions accepted in front of the makabons. Oath will be taken from injured clan members not to retaliate against the perpetrators until investigations are finalized and decisions are made. Once decisions are made after investigation of the matter, acts of imposing punishments and compensation payments are done up on the clan to which the perpetrator belongs together with feast and rituals. Compensations are given in kind (by giving animals) or in terms of money as per the prescriptions of afar customary law (mada'a). According to informants, the customary law specifies the compensation for the lost human life as 100 camels.

\section{PROCEDURES FOR MOBILITY}

One key feature of pastoral livelihood is that pastoralists move from place to place in search of water and grazing lands. The gender-based division of labour in all study sites presupposes that women are not primary participants in mobility. They are left at home to do domestic activities.

Mobility pattern of Afar pastoralists is clear; each clan member knows the site it can use, duration of stay in the satellite camp sites and return to main settlement sites. Even the distances covered are well known (Getachew 2004). Mobility also involves procedures. According to DCG (2004), a team of people who monitor the state of the rangeland before allowing herds to use it guides any movement of people and herd. This team is locally termed as Eddo that literally translated to range scouts. The team has to get the consent of the host 
community to use enclosures which can be allowed only after negotiation. There are also critical pre-conditions that outsiders should respect and include: that access is allowed only for lactating and young stock; that they have to make sure that all authorized animals are free from any apparent disease; that they access such grazing reserves for only a pre-defined period of time.

Every clan or a specific pastoral territory has representative vested with the responsibility of managing the affairs of travellers (mostly his kin groups) and negotiating with people in the area of destination on behalf of the people who accompany him in the journey (DCG, 2004). When there is a problem of managing movements, conflicts arise. In addition, other emerging factors may create conflict. Meier et al. (2007) had previously noted that the causes and dynamics of conflicts in Ethiopia are changing due to a number of factors, including environmental degradation, shrinking grazing lands, climate change and political instability.

Conflict can sometimes be attributed to physical mobility in search of scarce resources. However, all forms of conflict in the study area can't be interpreted in terms of pastoralist mobility. The mobile nature of the study communities complicates the nature of conflict by giving it a social background besides its resource-oriented nature. According to Alemayehu (2016), the likelihood of mobility to invite violent conflict is imminent. He said that mobility and conflict have a role reversal kind of relationship. At times mobility triggers conflict, at another conflict causes mobility. Especially when there is no traceable kinship between the migrating group and the host community, the likelihood of conflict is higher.

The process of conflict management in the study area incorporates different techniques such as negotiation, mediation and arbitration. The procedures in each case may diverge. But in the context of the three kebeles, all of them rely on social processes as people should go along with one another.

In the previous researches, a variety of techniques have been identified and employed in conflict management efforts that are related in one way or another the above three techniques. The following are the most prominent: First, conflicting parties are brought together to establish a mutual agreement. Second, governments or third parties to the strife may directly intervene to introduce or impose a decision. Third, new initiatives, programmes, or institutional structures (for example, elections) are implemented to address the conflict in question. Fourth, contending parties are compelled or coerced to utilize previously established means of resolution or containment. Fifth, government or another third party may use coercion to eliminate or instil fear among one or all those engaged in a given conflict, leading to subsidence (Miller \&King, 2005).

In the case of Afar, Getachew (2004) identified three forms of traditional conflict resolution. These include, Malbo, Detto and Billa-ara. In Aba'ala and its surrounding areas, the institutions take two forms; i.e Malbo and Gereb. Malbo is devoted to mitigate local conflict cases. But Gerebis a jointly established institution responsible for alleviating inter-ethnic disputes. In both Malbo and Gereb assemblies, a group of prominent elderly personalities involve in a chain of negotiations and arbitration processes to resolve conflicts in an orderly and transparent manner (Kelemework, 2001).

Getachew (2004) defined "Billa-ara" as a process of peacemaking between two different Afar clans where members of the traditional jury who are elders selected from different clans, other than the clans involved in conflict, engage in mediation. This is because of greater respect for elders in the community. Although peace committees exist in the kebeles under study, no joint customary institutions like Gereb are organized yet to manage sporadic conflict between the Afars and Amharas. This allows conflicts to perpetuate and escalate.

\section{The Role of Institutions in Conflict Resolution}

The afar people in Hiddelu, Garriro and Finto have hierarchical system of social organization and kin-based networks. They combine traditional and formal systems of administration where both channels are used to regulate members' day to day activities including cases of conflict. But in most cases, formal governmental organizations are of secondary importance to solve conflicts. 
Conflicts arise due to different factors. The first factor is rivalry for resource. Major resources of the study community include range land, water, whose availability is insufficient unlike a huge land mass available for mobility. Awra and Mille Rivers are of vital significance in the three kebeles and further. They are being utilized for watering animals and irrigation activities. However, Land and water are sources of conflict in Garriro, which unlike what is found in other sites, is very serious.

The other factor for conflict is the mobile nature of the study community. The conventional mobility is strengthened by the El Nino related drought in the year 2016 in which we witnessed massive exodus of pastoralists. Mobility is a triggering factor for Social conflict. During the drought season, the communities move in different direction and distance as far as Habru, worebabu, Teru, Yallo, Asayta and Gewane. In the process they come in conflict with others clans especially when there is Deso (enclosure).

Conflicts that occur within the people of the same clan are mostly mild disputes that are quickly adjusted. In most cases, intra ethnic and inter-personal conflicts are handled by traditional institutions of conflict management. The main actors include the elders, clan leaders and Fi'emat aba. Inter-ethnic conflicts are also sometimes dealt by indigenous institutions. But, when they fail to successfully control the conflict situation, the formal administrative agents intervene.

In the study community, the institutions of conflict management are legal courts, sharia courts and customary institutions. Conflicts among close friends or neighbours especially on matters of property inheritance, marriage, divorce and family are within the jurisdiction of Sharia courts. Customary institutions persisted over generations and are fundamental for maintaining peace and resolving conflict. They mostly deal with intraclan or intra-group conflicts. They usually address conflicts over such issues as natural resource utilization, communal property sharing, cattle raiding, revenge killing and absuma ${ }^{6}$ marriage. Furthermore, political conflicts of inter-ethnic or inter-group nature fall within the jurisdiction of the formal legal and administrative agents.

The process of conflict management through customary channels follows negotiation, mediation and arbitration techniques. While in case of formal mechanisms, arbitration by District administration is the usual mode of handling conflict in the study area.

\section{PreferRed Mechanism of Customary Mechanisms}

The results of data analysis showed that under the absence of un-escalated conflict, customary mechanisms are preferred by the indigenous people in the area. They have relative advantages in terms of responding to crises quickly; reduce the resources used for court cases, thereby saving scarce public funds. In addition, they are seen as more accessible, affordable and fair (Abebe, 2011). They are also advantageous in that they do not seek mere restitution and lifting of injustice. They simultaneously strive to avert ruptures in social relations and to create conditions conducive to peace in the post-conflict future (DCG, 2004).

Formal interventions of the past are not adequate to solve conflict particularly in Chifra and Habru District. Likewise solitary use of traditional alternative ways has some limitations. To take advantage of both methods, government institutions are engaging with the indigenous systems. This institutional support from modern legal set-ups along with the internal integrity of the indigenous institutions themselves has contributed to the effectiveness and continued strength of the latter (Kelemework, 2001).

But a more proactive engagement is required from official agencies. Study participants suggested that the various agents of the government shall activate a joint peace committee, demarcate the territory through

8 Absuma marriage is a customary arranged marriage practice of the Afar people. It is a cross-cousin marriage in which men of close relation claim the right to marry a girl by virtue of their blood ties to her. The girl is traditionally not expected to turn down marriage request from a man of her close relative. 
judicial process or initiate a development project on the disputed area that will benefit both parties, manage day to day security by dispatching police.

\section{CONCLUSION}

A study was conducted in three sites of Afar region on mobility, conflict and conflict management in the year 2017. The collected data showed that mobility is performed by both the pastoral and agro-pastoral communities as a way of coping drought conditions, a strategy of efficient resource utilization and as a means of information exchange. The direction and distance covered during mobility varies from one study site to another. The duration of stay is also determined by availability of water and pasture.

Mobility is a social process and therefore sometimes associated with conflict. This research shows that mobility is in itself not the cause of conflict but in most cases it is a triggering factor. Other underlying factors are causing the tension. The issues of resource and elitist mobilizations remain to be the fundamental source of the problem. Therefore, in order to solve an emerging conflict, the underlying causes of tension need to be addressed.

The nature of conflict varies from one area to another. Unlike other study sites, the conflict in Garriro involves Afar clans and neighbouring Amhara people. But it is not caused by differences of values among the two communities. What makes it different is its inter-group type and its sever consequences resulting in loss of human and animal lives. In this case, conflicts are not completely solved. But regular attempts of concession or cooling down tensions is made by representatives of the conflicting parties, particularly elders.

There are three institutions dealing with conflict in the study community these are Sharia courts, customary institutions and legal Courts. Sharia courts and judicial process are formal arrangements while the customary ones are informal. The parties involved in each case are different or they may come together at some point depending of the complexity of conflict. Above all, informal channels are essential and effective for the majority of the study participants. They follow negotiation, mediation or arbitration techniques in their functioning.

Certain limitations of informal mechanisms are expected to be filled by formal government intervention. However, this role of government is reported to be insufficient in case of Garriro where the administrative is not active to respond to the row between Badhito and Mosesa(settled adjacent to Garriro) clans over land and even in Garriro itself. However, the political transition that is brought recently in to effect is believed to avoid such deficiencies. It further paved the way for an extra-regional negotiation and compromise to bring peace and order for Amhara and Afar people together.

\section{RECOMMENDATION}

o Since conflict is intergraded to drought driven mobility, there should be strong early warning system to maintain the planned mobility of pastoralists .

o Joint conflict management institutions shall be established for the Afar agro-pastoralists and Amhara peasants.

o The started inter-community dialog shall be strengthened by regional government units of Afar and Amhara and Civil Society Organizations.

o Any pastoral development program in the study sites should hold conflict management task as its primary agenda. Particularly, water source development projects should integrate conflict resilience strategies. They should consider the joint benefit of conflicting communities.

o Potential conflict zones or hot spot areas (like one that is found in Awra district where villagization takes place and other kebeles of the same district neighbouring North Wollo) shall be identified and seriously considered at this time before conflict actually happens. This is because of the danger of conflict spill over in to other areas once it occurs. 
o Perennial river originating from the highland Amhara region and flowing towards Afar territory shall be used by the agreement of both regions.

o The major problem of precipitating conflict at the current time is not because of absence of prior efforts of resolution. Rather because of failure of parties to comply to such resolutions. So, third party (either NGO's like GIZ or government) shall initiate the parties' compliance to previous agreements and effect concessions.

o Rules and Systems of Resource utilization at each clan level shall be studied in detail

o The formal administrative body should be active to supervise the functioning of customary institutions. But it does not mean that the political elites degraded the power of traditional leaders. Rather, strong institutional support shall be extended to them. Their capacity should be built through training and dialogue. In addition, the mandate of sharia courts shall be expanded at least in Afar region to better support other institutions of conflict management.

\section{REFERENCES}

1. Abdulatife M, Ebro A. (2015). Assessment of Pastoral Perceptions towards Range and Livestock Management Practices in Chifra District of Afar Regional State, Ethiopia. Forest Res 4(144).

2. Abebe A. (2001). Indigenous Mechanisms for the Prevention and Resolution of Conflict: The Experience of the Oromos in Ethiopia. Abstract of paper presented at the Second Annual Workshop on 'Conflict in the Horn: Prevention and Resolution' 8 Juna, Ethiopia.

3. Akuru-Aja, A. (2007). Basic Concepts, Issues and strategies of Peace and Conflict Resolution: Nigeria-African Conflict Case Studies, Enugu: Keny\& Bros.

4. Alemayehu D. (2016). Mobility and Conflict: Persistent Challenges in Expanding Access to Education Among Pastoralists of South Omo, Ethiopia. Ethiopian Journal of Education \& Science, 11(2).

5. Bekele H. (2010). Conflicts between Afar Pastoralists and their neighbours: Triggers and motivations. International journal of conflict and violence, IJCV: 4 (1), 134-148.

6. Coser, L. (1995). The Functions of Social Conflict. Glencoe, Free Press.

7. DCG-Ethiopia. (2004). Indigenous Rangeland resources and Conflict Management by the North Afar Pastoral Groups in Ethiopia. (Report No.31). Mekele, Ethiopia: Yayneshet T. and Kelemework T.

8. DejeneA \& AbdurahmanA. (2001). The Root Causes of Conflict among the Southern Pastoral Communities of Ethiopia: A Case Study of Borana and Degodia. Report of Ethiopia National Workshop, Ethiopia: OSSREA.

9. FDRE (1995). Constitution of the Federal Democratic Republic of Ethiopia. Federal NegaritGazeta. P.29

10. FDRE Pastoral Community Development Project PCDP-3 and Regional Pastoral Livelihood Resilience Project (RPLRP). (2013). Social Assessment Report (Final). Addis Ababa.

11. Getachew, K. (2004). Settlement among the Afar pastoralists of the Awash valley. In Pankhrust A. \& Piguet F. (Eds). Migration, Resettlement and Displacement in Ethiopia, (pp.222-242). Addis Ababa. Ethiopia: ESSSWA.

12. Kelemework T. \& Mitiku H. (2001). Indigenous Institutions of Conflict Resolution among the Ab'ala Afar of Northeastern Ethiopia. Report of Ethiopia National Workshop, Ethiopia:OSSREA.

13. Løber T. \& Worm P. (2015). Investigating Complex Power Relations and Emerging Ethnic Identities. Roskilde University, ENSPAC. 
14. Meier, P., Bond D. \& Bond J. (2007). Environmental influences on pastoral conflict in the Horn of Africa. Political Geography, 26(6), 716-735.

15. Miller, C.E. \& King, M. E. (2005). A Glossary of Terms and Concepts in Peace and Conflict Studies. 2nd Edition, Geneva: University for Peace.

16. Mohammed T. (2001). The Fundamental Causes of Armed Conflict in Human History: Reinterpretation of Available Sources. Report of Ethiopia National Workshop, Ethiopia: OSSREA.

17. Pankhrust A. \& Piguet F. (2004). Contextualizing Migration, Resettlement and Displacement in Ethiopia. In Pankhrust A. \& Piguet F. (Eds). Migration, Resettlement and Displacement in Ethiopia. (pp.1-30), Addis Ababa, Ethiopia: ESSSWA.

18. PFE, IIRR and DF(2010). Pastoralism and Land: Land tenure, administration and ude in pastoral areas of Ethiopia. Kenya, Nairobi.

19. Sandford S. \& HabtuY.(2000). Emergency Response Interventions in Pastoral Areas of Ethiopia, Unpublished report for DFID, London.

20. Swanstrom, N.P. \& Weissmann, M.S. (2005). Conflict, Conflicts Prevention, Conflict Management and Beyond: A Conceptual Exploration. A publication of Central Asian Caucasus institute, Silk Road Studies Program (www.silkroadstudies.org).

21. Tesfay, Y. \& Tafere, K. (2004). Drylands Coordination Group Report No. 31 (November2004) Drylands Coordination Group c/o Noragric.

22. Turner M.D., Ayantude A.A., Patterson E.D. \& Patterson, K.P. (2004). Farmer-herder relations and conflict management in agro-pastoral zone of Niger. University of Wisconsin, Madison, USA.

23. Van den Akker, E., Berdel, W., \& Murele, J. N. (2015). Reversing Natural Degradation into Resilience: The Afar Case. In: "Conference on International Research on Food Security".

Citation: Abdelah Alifnur. "Managing Mobility Driven Conflict in the Border Areas of Afar Region, Ethiopia" American Research Journal of Humanities and Social Sciences, vol 5, no. 1, 2019, pp. 1-19.

Copyright (C) 2019 Abdelah Alifnur, This is an open access article distributed under the Creative Commons Attribution License, which permits unrestricted use, distribution, and reproduction in any medium, provided the original work is properly cited. 